\title{
Enhancing Business Students' International Capabilities Through Global Education Programs
}

\author{
Aristides R. Baraya, (Email: abaraya@selu.edu), Southeastern Louisiana University \\ Michael C. Budden, Southeastern Louisiana University \\ Rusty L. Juban, Southeastern Louisiana University
}

\begin{abstract}
Today, the development of a global vision is the cornerstone that guarantees personal, economic and social development, improves competitiveness, and strengthens democracy. Future business professionals will need to understand international business patterns and cultures in order to successfully work in corporations in either the United States or abroad. One way to achieve these goals is through the use of study abroad programs. Study abroad programs develop cross-cultural awareness as well as the interpersonal and professional skills necessary to operate in a changing business environment.
\end{abstract}

A common perception of North Americans is that they are in general ethnocentric and resist efforts to internationalize. While this may or may not be true for all those who reside in the United States, it is undeniable that future college graduates require a better education in international business and cross-cultural differences. The Association to Advance Collegiate Schools of Business International (AACSB) has risen to this challenge by requiring participating schools to include a global perspective in their business education programs. In accordance with AACSB accreditation, colleges and universities must incorporate into their mission a focus on "strong and growing global economic forces" (AACSB Standards for Business Accreditation, 1991). For business schools, this entails covering topics that convey to students the United States' role in the global environment and understanding economic and cultural dynamics that play a role in transactions between businesses in other countries.

Teaching the intricacies of international business law and the difficulties associated with marketing to individuals of a different language cause can lead to a diminished learning environment in traditional classroom settings. In response to AACSB's charge to improve education on international issues, some schools have stepped out of the classroom and literally moved courses into the global marketplace (Pretzels \& Curico, 1996). This paper discusses the rationale for experiential education programs, the benefits of these initiatives to students, and current trends in international study abroad programs.

\section{THE BASIS FOR STUDY ABROAD PROGRAMS}

Q nderstanding global strategies, international relations, and multicultural encounters is essential to a university education. Speaking on the topic of education and international issues, former President Bill Clinton said, "To continue to compete successfully in the global economy and to maintain our role as a world leader, the United States needs to ensure that its citizens develop a broad understanding of the world, proficiency in other languages, and knowledge of other cultures" (The Center for Global Education, 2004). Internationalization is a major trend in higher education; it is also a worldwide phenomenon. Changes in social, political, economic, and technological environments generate various challenges to universities worldwide (Ortiz, 2004). 
The globalization process requires international business students in the United States to function adequately in an integrated world economy. Future business professionals will need to understand international business patterns and culture in order to successfully work in either the United States or abroad. These changes require that American universities and colleges develop more programs and activities aimed at providing an international perspective and cross-cultural skills to American students (Altbach, 2002).

As evidenced by new pedagogical methods, university faculty are moving away from rigid, linear forms of teaching that can be divided into neatly ordered lessons and moving toward holistic forms that embrace a degree of uncertainty. This is necessitated by the fact that education in the twenty-first century is a dynamic and continuous process. Academics should no long be content to close themselves within the walls of the classroom and lecture on world culture and business practices. Modernization of business curriculums and strengthening international learning for students are fundamental pillars that mark a new era of instruction in business education. Internationalization of business curriculums is not an option, but a necessity in business schools to achieve the global vision of their students (Altbach, 2002)

According to experts in business education, lecture based courses focus primarily on the transfer of conceptual knowledge (Whetten \& Clark, 1993). Conceptual knowledge, which relates to the association of facts and major themes, is an important element of introductory courses. This form of knowledge provides a strong foundation upon which students can build more complex mental models and is essential when students do not possess a high degree of experience or maturity. However, there are problems associated with this method of learning especially when teachers accentuate rote memorization of definitions and sanitized company cases from textbooks. This "information dump" does little to capture the dynamic nature of business knowledge. According to Nadkarni (2003), business courses "are qualitative, applied, and subjective, where student learning is comprised not only of the conceptual understanding of the domain, but also of the application of these concepts in a variety of "real" situations." Due to the subjective nature of many business problems, delineation of right or wrong answers can prove difficult. The premise of a contingency approach to solving business problems requires that students possess a much broader and deeper understanding of the issues facing today's organizations.

The best instructional style depends on a combination of factors (Brookefield, 1984). Research shows that students have different learning styles for acquiring particular skills and knowledge. The key for faculty is finding the right match between a student's learning style and the appropriate instructional methods to produce favorable learning outcomes. For example, elementary math is best taught to young students using the application of simple problems. On the other hand, advanced biology students learn better when there is synthesis and evaluation of knowledge. In general, experts agree that adult learning improves when students use a proactive perspective to education (Nadkarni, 2003).

As a learner matures, learning styles that engage students to acquire skills and knowledge are desired. However, learner maturity does not always correspond to the age of the learner. Maturity relates to a learner's level of experience and motivation to acquire new knowledge. More mature learners possess greater existing knowledge, more accurate expectations, and existing attitudes toward upcoming events. Knowles (1984), in his classic work on learning styles classified adult learning as being andragogical, more self-directed, and pedagogical, more teacher driven. According to Knowles, the teaching methods that work best with more mature learners are andragogical methods. The reason for this being adult learners prefer greater power and control the learning process.

From the literature on business education, two points are clear. First, students learn best when program curriculum include diverse teaching methods which allow for a match in student learning styles. Second, adult learners perform better when allowed to be more actively involved in the search for knowledge. This has led to the development of experiential courses that emphasize personal application and allow students to develop their own attitudes and beliefs on important topics. Experiential courses are proactive and self-directed. These programs build upon information provided in foundational courses and require students to engage in action-oriented tasks designed to help them learn through their own individual experience (Hopkins, 1999). Study abroad programs are an example of experiential learning. 
Study abroad offers the opportunity to see other countries and savor other cultures first-hand while earning academic credits in their curriculum. Study abroad is a unique and excellent way to achieve cross-cultural awareness as well as to develop one's own personal and professional skills in operating in new and changing environments. A mixture of innovations in business schools' curricula, study abroad programs, and new initiatives that promote international awareness, allow students to become more consciousness and knowledgeable in today's world.

Study abroad programs offer students an opportunity to meet with individuals involved in multi-national and international government agencies, politics and private business initiatives. This interaction focuses on a working, learning, and problem-solving context, as opposed to being a tourist. Students are exposed to other cultures in order to learn how business is conducted outside of the United States and to better understand how others view life and business dealings.

\section{TYPES OF STUDY ABROAD PROGRAMS}

Due to increased interests in study abroad, universities and colleges offer an assortment of programs. Study abroad programs include a combination of in-depth language studies, cross-cultural studies, and internships. Study abroad programs in business schools focus mainly on cultural studies incorporating student tours to host country businesses, governmental entities, and economic development agencies. Business internships allow students to work in a foreign company's human resource, marketing, research or other departments. Students may also choose a variety of industries including: consulting, finance, hotel management, information technology, sports management, and telecommunications, to name a few.

Business schools offer a variety of locations for international study. For example, at New York University, students may choose from several European locations including Florence, London, Madrid, Paris, and Prague. In these modernized cities, students experience first hand the developing power of a unified Europe. The University of Texas at El Paso allows students to participate in programs in China due to a cooperative grant between the U.S. government and Hong Kong. The University of Pittsburgh grants academic credit for participation in a unique program called Semester at Sea where the student travels by ship to different locations. At Southeastern Louisiana University, business students travel to Costa Rica, Germany, Austria or France to learn about business and culture in those countries. Costa Rica, an uncommon destination for studying business abroad is Southeastern's most popular destination. Costa Rica provides students the opportunity to view a country that has made the successful transition to political and economic stability in a turbulent Central America.

The length of time students spend in study abroad programs vary. Programs may require students to spend up to one to two years in residence in another country. These programs include courses taken in English or in a native language at a local university and/or participation in a work abroad program. Other programs require that students commit to a semester, or a portion of the semester abroad. Recent data shows the majority of study abroad programs take place during the short summer semester (Hofius, 2004).

Study abroad programs come in different forms including: direct enrollment in post-secondary institutions, transnational course-based programs, transnational or freestanding research and field study, and internship programs. Direct enrollment courses utilizing college faculty is common. However, a growing trend for study abroad programs is to offer courses through a consortium of universities in a variety of countries. These consortiums coordinate efforts between schools and provide students greater opportunities to take courses in different locations.

The American Institute for Foreign Study (AIFS) organizes programs for approximately 40,000 students annually. These programs allow students to "pick and choose" the program that is right for them depending on experience and costs. European Study Abroad (EUSA) focuses on internships in Europe and operates study abroad programs in several countries including Belgium, France, Ireland, Italy, Spain and the United Kingdom. Programs such as EUSA contract with North American universities to meet the high demand of American students interested in internships abroad. If students desire a unique study abroad experience, some universities allow students to develop independent study and internship courses. As a rule, such programs are monitored by the sponsoring university and must meet all of the guidelines of traditional study abroad courses. Finally, private tour companies with no official 
university affiliation provide a wealth of knowledge to students on opportunities to study abroad. These companies act as tour guides and lecture arrangement managers and offer discounted travel incentives for groups of university students to experience foreign cultures and locations.

\section{OBJECTIVES, BENEFITS AND OPPORTUNITIES}

From a university's perspective, business study abroad programs incorporate a number of important objectives. However, each university program may differ depending upon the focus of the curriculum, the type of program (i.e. internship versus cross-cultural studies), the location visited, and the experience of faculty. At Southeastern Louisiana University, the College of Business and Technology affirmed a broad range of goals for study abroad including:

- To Increase awareness of cultural diversity and international business

- To promote cross-cultural dialogue that stimulates and prepares students for worldwide opportunities in today's global marketplace

- To strengthen international relationships between the College and international business agencies and governmental entities

- To encourage a challenging atmosphere that inspires student growth and development, both personally and professionally

- To promote international relationships among students

- To promote lifelong friendships that strengthen university-student relationships

- To offer practical applications of classroom theories

- To incorporate graduate and undergraduate students in research projects that involve a large component of field work and an international dimension

- $\quad$ To broaden student horizons beyond the classroom

The research on study programs agrees that there are important benefits to be gained from these programs. In a survey of two hundred and thirty two study-abroad college students, it was found that participating students reported (a) enhanced cross-cultural skills, (b) greater proficiency in the subject matter, and (c) greater socialization (Kitsantas, 2004). In reference to Title VI, which supports educational innovations, "the research on study abroad programs show several benefits of study abroad programs including: critical thinking skills; the ability to communicate in more than one language; the ability to communicate across cultural and national boundaries; and the ability to make informed judgments on major personal and social issues based on the analysis of various perspectives" (US Department of Education, 2004).

For students, there are additional reasons to consider studying abroad. First, students gain academic credit for participating in study abroad programs. When students see that three or more credit hours can be earned for what is often mistakenly advertised as a "summer vacation," students may be tempted to take part in university sponsored travel programs as opposed to individual excursions. Second, study abroad programs are a good way for students to build their resumes. For students who lack international experience, participation in a study abroad program may show prospective employers that a student is internationally minded, willing to tackle new projects, and comfortable in diverse surroundings. Finally, study abroad programs are truly the experience of a lifetime. There are many memorable experiences that can be gained from being part of a study abroad program. The opportunity to travel with peers to exotic locations and to gain knowledge of other cultures makes travel abroad appealing. The reduced costs obtained through the university and the fact that study abroad programs can be paid for with student loans adds to the programs overall attractiveness.

\section{RECENT TRENDS IN STUDY ABROAD PROGRAMS}

With the events of 9-11, it might appear that students would be less open to opportunities to travel abroad. However, data shows that the number of students interested in study abroad programs has increased. A recent survey of high school students found that forty-eight percent said they had plans to study abroad. According to the Institute of International Education (2004), in the 2002-2003 academic year, 174,629 US students studied abroad. This 
represents an 8.5 percent increase over the previous year. Also, there was a five percent increase in foreign students studying in the United States. Looking at countries participating in study abroad, only China, due to the SARS epidemic and the Middle East saw fewer visiting students.

The National Association of International Education recently performed a survey of study abroad advisors from twenty-five universities and three study abroad consortiums (Ludwig, 2004). One of the main purposes of the study was to determine future trends for study abroad programs. Using information from interviews and current literature, Ludwig determined the following trends are expected to occur over the next 10 years:

- There will be continued growth in the market of students available for study abroad programs due to a projected increase in 18-20 year old college students. While there are projected increases in enrollment for several age groups, evidence shows that traditional age college students are more likely to participate in study abroad programs.

- Greater educational diversity of high school graduates will result in larger numbers interested in study abroad programs. Changes in high school education curricula will result in college students who are better equipped for study abroad programs due increased language skills, greater ability to use technology to maintain high levels of academic performance and greater educational experience.

- An increase in education styles has created a situation where students no longer look to a four-year model of college education. With a greater number of college age students working and a number of non-traditional students going to school part-time, students are open to a variety of courses including internships.

- Due to an increasing demand for international occupations, there is greater interest in educational opportunities that focus on international issues.

Finally, there are other trends developing that are less heartening to study abroad coordinators. In a poll conducted by the American Council on Education, researchers discovered what they called an international education paradox (A.C.E, 2000). Compared to American recognition of globalization as a competitive advantage and students' plans to study international issues, relatively few students (only 3 percent) participate in a study abroad program before they graduate. Participation rates in the United States pale in comparison to Australia where there was a 30 percent increase in study abroad students last year alone. In addition, while the United States is still the most preferred location for international students, other countries such as Britain and Australia are rapidly catching up. In Australia's 38 universities, there are an average of 1,500 international students per campus compared to an average of 150 students per campus in the United States.

There are several possible explanations for the low participation rates of students including misconceptions by students regarding program availability and content, and concerns over time and money. A survey of 656 college of business students at seven universities found that 29.6 percent of those responding assumed incorrectly that their university did not have a study abroad program (Alber-Miller, Prenshaw, \& Straughan, 1999). This number was even higher when students were asked if programs were offered for business students -50.9 percent of the students were not aware that their university currently offered a study abroad program in business. The same study also found that students assumed a foreign language was necessary to participate in study abroad (41.2 percent). Study abroad programs can also be perceived as a drain on student's time and finances. As a greater number of college students work, there is less discretionary time to participate in courses that require a semester spent in another country. Study abroad may also be seen as prohibitively expensive for students on a tight budget or attending school on loans and grants.

Another disconcerting trend is that the average length a student's stay in a host country is shrinking (Wheeler, 2000). Long semester abroad programs are being replaced with stays of several weeks. Of the students who studied abroad in the 2001-02 school year, more than half were involved in programs that ran for less than a semester. Shorter programs raise issues of quality control and the need for program quality standards. It should be stressed however, that no one has yet determined if shorter programs do less to increasing cultural awareness than do long programs. 
In closing, it should be noted that study abroad programs play an important role in the internationalization of students, faculty, and society as a whole. The energy and excitement created by these programs impact participating faculty, fellow students, and individuals in other countries who come in contact with students. President George W. Bush addressed this issue when he said, "The relationships that are formed between individuals from different countries, as part of international education programs and exchanges, can also foster goodwill that develops into vibrant, mutually beneficial partnerships among nations" (The Center for Global Education, 2004).

\section{REFERENCES}

1. “AACE Reports Show Need for Increased Participation in International Ed Programs", Higher Education and National Affairs, 11/20/00, Vol. 49, No. 21.

2. Albers-Miller, N. D.; P. J. Prenshaw, and R. D. Straughan. "Student perceptions of study abroad programs: A survey of US colleges and universities". Marketing Education. Vol. 9, Iss. 1, p. 29-36.

3. “Altbach, 2002. Perspectives on Internationalizing Higher Education”. Center for International Higher Education, Boston College.

4. “Association to Advance Collegiate Schools of Business International”. Standards for Business Accreditation, St. Louis, MO: AACSB, 1991.

5. Brookefield, S. D. 1984. "Self-directed adult learning: A critical paradigm". Adult Education Quarterly, Vol. 35, Iss. P. 59-71.

6. Hofius, S., 2004. "Studying abroad hasn't lost its appeal”. USA Today, 10/15/2004.

7. Hopkins, R., 1999. "Studying Abroad as a form of experiential education". Liberal Education. Vol. 85, \#3. p. 36-42.

8. Kitsantas, A., 2004. "Studying abroad: The role of college students' goals on the development of crosscultural skills and global understanding". College Student Journal. Vol. 38, Iss. 3; p. 441

9. $\quad$ Knowles, M. S., 1984. Andragogy in action. San Francisco, CA: Jossey-Bass.

10. Nadkarni, S., 2003. "Instructional Methods and Mental Models of Students: An Empirical Investigation". Academy of Management Learning \& Education, Vol. 2, Iss. 4.

11. Ludwig, M., 2004. "The next ten years: Trends affecting study abroad participation for U.S. Students", NAFSA: Association of International Education.

12. Ortiz, J., 2004. "International Business Education in a Global Environment: A Conceptual Approach". International Education Journal. Vol. 5, No. 2, p.255-265.

13. Praetzel, G., J. Curico, J., 1996. "Making studying abroad a reality for all students". International Advances in Economic Research. Vol. 2, p. 174-183.

14. "The Center for Global Education”, 2004 (website). http://www.lmu.edu/globaled/.

15. US Department of Education, 2004. "Study abroad: Enhancing international and area studies education". U.S. Department of Education.

16. Wheeler, D. 2000. "More students study abroad, but their stays are shorter". Chronicle of Higher Education, Vol. 47. Iss. 12 p. 74-76.

17. Whetten, D. A., and S. C. Clark, 1996. “An integrated model for teaching management skills'. Journal of Management Education, 20: 152-181. 